\title{
AN EXPERT SYSTEM TO EVALUATE ENVIRONMENTAL SENSITIVITY: A LOCAL - SCALE APPROACH TO DESERTIFICATION RISK
}

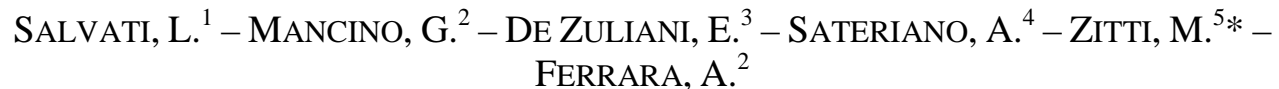 \\ ${ }^{I}$ Italian National Agricultural Research Council - Centre for the Study of Plant-Soil \\ Relationships (CRA-RPS) \\ Via della Navicella 2, I-00184 Rome, Italy \\ (phone: +39-6-700-5413; fax: +39-6-700-5711, e-mail: bayes00@yahoo.it) \\ ${ }^{2}$ Department of Crop Systems, Forestry and Environmental Sciences, University of Basilicata \\ Via dell'Ateneo Lucano 10, I-85100 Potenza, Italy \\ (phone: +39-761-0971-205-241; fax: 39-761-0971-205-311, \\ e-mail:agostino.ferrara@unibas.it) \\ ${ }^{3}$ Macchiatonda Natural Reserve \\ Via del Castello 40, I-00050 Santa Severa, Italy \\ (phone: +39-766-5733032; fax: +39-766-571097, e-mail: info@ riservamacchiatonda.org) \\ ${ }^{4}$ Via G. Facchinetti 85, I-00161 Rome, Italy \\ ${ }^{5}$ Central Office of Crop Ecology (CRA-CMA), \\ Italian National Council of Research in Agriculture, \\ Via del Caravita 7a, I-00186 Rome, Italy \\ (phone: +39-6-6953-1212; fax: +39-6-6953-1214; e-mail: mzitti@libero.it) \\ *Corresponding author \\ e-mail:mzitti@ucea.it \\ (Received $26^{\text {th }}$ September 2011; accepted $5^{\text {th }}$ September 2013)
}

\begin{abstract}
Under scenarios of increasing climate aridity and human pressure, Ecosystem Sensitivity to Desertification (ESD) is one of the most important targets for sustainable land management. This process is particularly complex in the Mediterranean region since it involves multifaceted, interacting factors that depend on endogenous conditions and exogenous pressures. Environmental indicators quantifying the ESD level at local scale should reflect the interaction among biophysical and socioeconomic factors that are (directly or indirect) associated to soil and land degradation. This paper illustrates a Geographical Information System (GIS) investigating the main factors determining ESD at land unit scale. This tool incorporates a Decision Support System (DSS) capable to simulate the effect of short-term environmental changes on the ESD (hereafter 'DSS-ESI'). The final output of the DSS-ESI is a composite index of land sensitivity to desertification (ESI) calculated separately for representative land cover types. The illustrated system was supplemented by a web-based interface which estimates the overall level of land sensitivity under different climate, population, and policy scenarios. The paper illustrates the main results produced by the DSS-ESI in a study site application (Basilicata, Italy) and comments about its applicability to other Mediterranean areas. Monitoring systems like the one illustrated here may support local-scale responses to mitigate land degradation in the Mediterranean basin.
\end{abstract}

Keywords: Decision Support System, Key Indicators set, Desertification, Climate change, Land use change, Land management. 


\section{Introduction}

In developed countries, Sustainable Land Management (SLM) is a key planning issue especially in traditionally agricultural regions (Briassoulis, 2005). In the Mediterranean basin, several factors, including climate variations and land use changes, influence the quality of the environment and the ecological dynamics of agroecosystems (Conacher and Sala, 1998). Under scenarios of increasing climate aridity and human pressure, Ecosystem Sensitivity to Desertification (ESD) is one of the most important targets for SLM (Costantini et al., 2009). This process is particularly complex in the Mediterranean region since it involves multifaceted factors that depend on endogenous conditions (e.g. the territorial context) and exogenous pressures (Salvati et al., 2008).

A sensitive area to desertification is defined as a land unit where environmental and socio-economic factors are not sustainable in the long-term (Basso et al., 2000). Environmental indicators quantifying the ESD level at local scale should reflect the interaction among biophysical and socioeconomic factors that are (directly or indirect) associated to soil and land degradation (Simeonakis et al., 2007; Salvati and Zitti, 2008; Costantini et al., 2009). As a matter of fact, severe degradation processes could result from a combination of poor land management together with dry climate, degraded soil, and poor vegetation cover. The identification of key variables producing critical environmental conditions is thus crucial to assess land degradation and to inform mitigation policies against desertification. Moreover, to define their individual contribution to determine the level of land sensitivity represents an important part of any desertification monitoring system (Kosmas et al., 2003).

From technical point of view, a considerable amount of data is required to estimate the level of ESD. To fill this objective, geographical and statistical techniques were used to manage different types of variables including nominal variables (e.g. crop type, tillage practices), binary variables (e.g. protected/non protected area), discrete variables (e.g. a soil system classification), ordinal variables (e.g. the degree of soil erosion, the level of organic matter content), and continuous variables (e.g. elevation). The complexity of the information needed to evaluate land sensitivity reflects the complexity of the question to be answered. By the contrary, from policy perspective, decision makers and stakeholders require simple, continuously-updated environmental indicators and brief reports documenting the possible changes in land sensitivity over time (Basso et al., 2000; D'Angelo et al., 2000; Feoli et al., 2003).

To reduce the information gap between science and policy in this deserving issue (e.g. Grainger, 2009), this paper illustrates a Geographical Information System (GIS) which investigates the main factors determining ESD at land unit scale incorporating a Decision Support System (DSS) to simulate the effect of short-term environmental changes on the ESD (hereafter 'DSS-ESI'). The final output of the DSS-ESI is a composite index of land sensitivity to desertification (ESI) calculated separately for the most representative land cover types in the study area. The illustrated system was supplemented by a web-based interface that estimate the overall level of land sensitivity under different scenarios of climate changes, land use changes, and policy enforcement.

The system presented in this paper refers to the Environmental Sensitive Area (ESA) framework and was specifically designed for local-scale desertification monitoring (Kosmas et al., 1999). The present study was enriched by a comprehensive DSS-ESI exercise carried out in a vulnerable water basin in Basilicata (Italy). Data from various sources including remote sensing, geographical and statistical data, as well as ad hoc 
field surveys, were used in this application. The illustrated DSS represents an original simulation tool for the evaluation of climate change, land use change, soil degradation, and environmental protection impact on the ESD.

\section{Materials and Methods}

\section{Data and variables}

The variables used to evaluate the level of ESD at local scale (hereafter called 'layers') were listed in Table 1 and fully described in the following paragraphs. The relationship existing between each layer and the process of land degradation was also described (Kosmas et al., 1994, 1999; Rubio and Bochet, 1998; Ferrara et al., 1999; Basso et al., 2000). Layers were selected according to four criteria: (i) documented relationship with desertification processes; (ii) availability at high-resolution spatial scale; (iii) low acquisition cost; and (iv) easy updating.

Table 1. Layers used in the evaluation of the ESD

\begin{tabular}{|c|c|c|}
\hline Theme & Layer name & Source \\
\hline Pedology & $\begin{array}{c}\text { Parent material, rock fragments, soil } \\
\text { depth, slope angle, drainage, soil texture }\end{array}$ & $\begin{array}{c}\text { Soil maps at 1:100 } 000 \text { scale and field } \\
\text { samplings }\end{array}$ \\
\hline Climate & $\begin{array}{l}\text { Rainfall, aspect, (Bagnouls-Gaussen) } \\
\text { aridity index }\end{array}$ & $\begin{array}{c}\text { Climatic maps at } 1: 250000 \text { scale and } 20 \\
\text { m ASTER Digital Elevation Model }\end{array}$ \\
\hline Vegetation & $\begin{array}{l}\text { Fire risk, protection against soil erosion } \\
\text { drought resistance, vegetation cover }\end{array}$ & $\begin{array}{l}\text { Remote sensing and land cover maps at } \\
1: 25000 \text { scale }\end{array}$ \\
\hline $\begin{array}{c}\text { Land } \\
\text { management }\end{array}$ & Land use intensity, policy enforcement & $\begin{array}{c}\text { Statistical data at municipal and infra- } \\
\text { municipal level }\end{array}$ \\
\hline
\end{tabular}

\section{Pedology}

Soil is a crucial factor determining the level of ESD. Soil properties are relevant for the study of desertification mainly because of two processes: (i) water storage and retention capacity, and (ii) protection against soil erosion. Soil quality was evaluated using data collected in soil survey reports and maps. Soil layers and sensitivity scores are reported in Table 2. 
Table 2. Soil variables and related scores

\begin{tabular}{|c|c|c|}
\hline Variable & Class & Score \\
\hline $\begin{array}{l}\text { Parent } \\
\text { material } \\
\text { (class) }\end{array}$ & $\begin{array}{l}\text { Shale, schist, basic, ultra basic, conglomerates, unconsolidated, clays, marl with natural } \\
\text { vegetation } \\
\text { Limestone, marble, granite, rhyolite, ignibrite, gneiss, siltstone, sandstone, dolomite marl, } \\
\text { pyroclastics }\end{array}$ & $\begin{array}{l}1.0 \\
1.7 \\
2.0\end{array}$ \\
\hline $\begin{array}{l}\text { Soil } \\
\text { texture } \\
\text { (class) }\end{array}$ & $\begin{array}{c}\text { L, SCL, SL, LS, CL } \\
\text { SC, SiL, SiCL } \\
\text { Si, C, SiC } \\
\text { S }\end{array}$ & $\begin{array}{l}1.0 \\
1.2 \\
1.6 \\
2.0\end{array}$ \\
\hline $\begin{array}{l}\text { Rocky } \\
\text { fragments } \\
(\%)\end{array}$ & $\begin{array}{l}>60 \\
20-60 \\
<20\end{array}$ & $\begin{array}{l}1.0 \\
1.3 \\
2.0 \\
\end{array}$ \\
\hline $\begin{array}{l}\text { Soil depth } \\
\quad(\mathrm{cm})\end{array}$ & $\begin{array}{c}\text { Deep }(>75) \\
\text { Moderate }(30-75) \\
\text { Shallow }(15-30) \\
\text { Very shallow }(<15)\end{array}$ & $\begin{array}{l}1.0 \\
2.0 \\
3.0 \\
4.0\end{array}$ \\
\hline $\begin{array}{c}\text { Drainage } \\
\text { (class) }\end{array}$ & $\begin{array}{l}\text { Well drained } \\
\text { Imperfectly drained } \\
\text { Poorly drained }\end{array}$ & $\begin{array}{l}1.0 \\
1.2 \\
2.0\end{array}$ \\
\hline Slope $(\%)$ & $\begin{array}{c}<6 \\
6-18 \\
18-35 \\
>35\end{array}$ & $\begin{array}{l}1.0 \\
1.2 \\
1.5 \\
2.0\end{array}$ \\
\hline
\end{tabular}

\section{Climate}

Climate quality was assessed using average annual precipitation (a crucial variable in vegetation growth), Bagnouls-Gaussen aridity index (composing long-term average precipitation and potential evapotranspiration); and aspect (which affects microclimatic conditions and soil erosion rate). The sensitivity scores associated to each climate layer are reported in Table 3.

Table 3. Climate variables and related scores

\begin{tabular}{c|c|c}
\hline Variable & Class & Score \\
\hline \multirow{2}{*}{ Rainfall (mm/year) } & $>650$ & 1.0 \\
& $280-650$ & 2.0 \\
& $<280$ & 4.0 \\
\hline \multirow{2}{*}{ Bagnouls - Gaussen aridity } & $<50$ & 1.0 \\
index (mm/mm) & $75-100$ & 1.1 \\
& $100-125$ & 1.2 \\
& $125-150$ & 1.8 \\
Slope aspect (class) & $>150$ & 2.0 \\
\hline \multirow{2}{*}{ North, NW, NE, plain } & 1.0 \\
\hline
\end{tabular}

\section{Vegetation}

Vegetation cover plays a pivotal role in the mitigation of degradation phenomena. Vegetation layers and the related scores used in the ESA system reported in Table 4. 
The quality of the vegetation cover was assessed through the following variables: (i) fire risk (which affects land degradation, soil erosion rates and biodiversity losses), (ii) protection against soil erosion (a key factor controlling the intensity of flooding and soil erosion), (iii) vegetation drought resistance (that indirectly indicates the capability of an ecosystem to adapt to climate aridity and severe drought episodes), and (iv) vegetation cover (reducing runoff and sediment loss).

Table 4. Vegetation quality layers and related scores

\begin{tabular}{|c|c|c|}
\hline Variable & Class & Score \\
\hline \multirow{3}{*}{$\begin{array}{l}\text { Vegetation } \\
\text { cover }(\%)\end{array}$} & $>40$ & 1.0 \\
\hline & $40-10$ & 1.8 \\
\hline & $<10$ & 2.0 \\
\hline \multirow{4}{*}{$\begin{array}{l}\text { Fire risk } \\
\text { (class) }\end{array}$} & $\begin{array}{l}\text { Bare soils, bedrocks; almonds, orchards, grapevines, olive groves, irrigated } \\
\text { annual crops (maize, tobacco, sunflower), horticulture }\end{array}$ & 1.0 \\
\hline & $\begin{array}{l}\text { Perennial grasslands, pastures, cereals, annual grasslands, deciduous forests, } \\
\text { evergreen forests (with Quercus ilex), shrublands, very low vegetated areas }\end{array}$ & 1.3 \\
\hline & Mediterranean maquis & 1.6 \\
\hline & Coniferous forests & 2.0 \\
\hline \multirow{5}{*}{$\begin{array}{c}\text { Soil } \\
\text { erosion } \\
\text { protection } \\
\text { (class) }\end{array}$} & $\begin{array}{l}\text { Evergreen forest (except conifers), mixed Mediterranean maquis, } \\
\text { evergreen forests (with Quercus ilex), bedrocks }\end{array}$ & 1.0 \\
\hline & $\begin{array}{c}\text { Mediterranean mquis, coniferous forests, perennial grasslands, pastures; olive } \\
\text { groves, shrubland }\end{array}$ & 1.3 \\
\hline & Deciduous forests & 1.6 \\
\hline & Almonds, orchards & 1.8 \\
\hline & $\begin{array}{l}\text { Grapevines, annual crops (cereals, maize, rice, oats, barley, grasslands), low } \\
\text { vegetated areas, bare ground }\end{array}$ & 2.0 \\
\hline \multirow{4}{*}{$\begin{array}{l}\text { Vegetation } \\
\text { resistance } \\
\text { to drought } \\
\text { (class) }\end{array}$} & $\begin{array}{l}\text { Evergreen forest (except conifers), Mediterranean maquis, evergreen forests } \\
\text { (with Quercus ilex), bedrocks, bare ground }\end{array}$ & 1.0 \\
\hline & Coniferous and deciduous forests, olive groves & 1.2 \\
\hline & Perennial grasslands, pastures, shrubland & 1.7 \\
\hline & $\begin{array}{c}\text { Annual crops (annual grassland, cereals, maize, tobacco, sunflower), low } \\
\text { vegetated area }\end{array}$ & 2.0 \\
\hline
\end{tabular}

\section{Land management}

The quality of land management was assessed according to the dominant use observed in each land unit. Five land use classes were used in the analysis: cropland, pasture land, natural areas including forests and shrubland, mining areas, and recreational areas (Ferrara et al., 1999). The two considered layers were the intensity of land use (LUI) and the estimation of the level of land protection policies (Table 5). The LUI in cropland was classified into three sensitivity groups based on the frequency of irrigation, degree of mechanization, application of fertilizers and agrochemicals, and crop type. 
The quality of management of pasture land was assessed by estimating the carrying capacity of the land unit and comparing it with the actual number of animals grazing the area. The sustainable stocking rate (SSR) expressed in animals per hectares can be calculated by the following equation:

$$
\mathrm{SSR}=\frac{\mathrm{X} \times \mathrm{P} \times \mathrm{F}}{\mathrm{R}}
$$

where $\mathrm{R}$ is the required annual biomass intake per animal (sheep or goat $187.5 \mathrm{~kg}$ animal $^{-1}$ year $^{-1}$, Kosmas et al., 1999), $X$ is the ratio describing grazing efficiency corrected for the biomass not produced during the latest growing season (grazed: 0.5, non-grazed 0.25 year $\left.^{-1}\right), \mathrm{P}$ is the average palatable biomass after dry season $\left(\mathrm{kg} \mathrm{ha}^{-1}\right), \mathrm{F}$ is the average fraction of soil surface covered by annual crops. Pasture LUI was defined by dividing the SSR by the actual stocking rate (ASR) (Ferrara et al., 1999). ASR was calculated as the livestock density (per hectare of available pasture land) according to data collected at municipal scale by the National Census of Agriculture. The ASR/SSR ratio was classified into three classes (see Table 5). In natural areas the LUI was defined by assessing the actual yield (A) and sustainable yield (S) obtained by regional administrative sources, field surveys, and remote sensing analysis. Then, the intensity of land use was classified into three classes based on the A/S ratio.

Mining activities have a great impact on soil quality. The LUI in mining areas was defined by evaluating the measures undertaken to control soil erosion like terracing, recovery of vegetation cover, and fire control. This evaluation was based on maps and quantitative information collected by regional administration land services and field surveys (Kosmas et al., 1999).

Finally, the diversification in several types of recreation activities as well as their effects on the environment requires the basic distinction between passive ad active recreation. Passive recreation includes activities with less impact on soil (walking, nature seeing, mountain climbing, swimming and similar activities). Active recreation, which represents a key pressure on land, includes skiing, cross country skiing games (e.g. sand rallies), etc. The quality of management is a function of both the size of demand as well as the management strategies and practices employed. The assessment procedure includes the assessment of the carrying capacity of the recreation area (maximum number of visitors permitted per year), the assessment of the actual number of visitors per year, the calculation of the ratio of actual to permitted (A/P) number of visitors per year. Finally the quality of land management was ranked as high if the ratio was equal or less than 1 , as low if the ratio was greater than 1 . The permitted number of tourists was calculated from data obtained at the municipal level while the number of arrivals was derived from official statistics surveys. The intensity of tourism development can be assessed following the procedure described for recreation areas (Ferrara et al., 1999). 
Table 5. Evaluation of land use intensity (LUI) in different land uses

\begin{tabular}{|c|c|c|}
\hline Class & Description & Score \\
\hline \multicolumn{3}{|c|}{ Cropland } \\
\hline 1 & $\begin{array}{c}\text { Local varieties are used, fertilisers and pesticides are not } \\
\text { applied, yields depends primarily on fertility of soils and } \\
\text { environmental conditions. Mechanisation is limited. In case } \\
\text { of seasonal crops, one crop is cultivated per year or the land } \\
\text { remain under fallow. }\end{array}$ & 1.0 \\
\hline 2 & $\begin{array}{c}\text { Improved varieties are used, insufficient fertilisers are applied } \\
\text { and inadequate disease control is undertaken. Mechanisation } \\
\text { is restricted to the most important such as sowing, fertilisers } \\
\text { application, etc. }\end{array}$ & 1.5 \\
\hline 3 & $\begin{array}{c}\text { Application of fertilisers and control of diseases are adequate. } \\
\text { Cultivation is highly mechanised. }\end{array}$ & 2.0 \\
\hline \multicolumn{3}{|c|}{ Pasture land } \\
\hline 1 & Low (ASR < SSR) & 1.0 \\
\hline 2 & Moderate $\left(\mathrm{ASR}=\mathrm{SSR}\right.$ to $\left.1.5^{*} \mathrm{SSR}\right)$ & 1.5 \\
\hline 3 & $\operatorname{High}(\mathrm{ASR}>1.5 * \mathrm{SSR})$ & 2.0 \\
\hline \multicolumn{3}{|c|}{ Natural areas (forests and shrubland) } \\
\hline 1 & Low $(\mathrm{A} / \mathrm{S}=0)$ & 1.0 \\
\hline 2 & Moderate $(\mathrm{A} / \mathrm{S}<1)$ & 1.2 \\
\hline 3 & $\operatorname{High}(\mathrm{A} / \mathrm{S} \geq 1)$ & 2.0 \\
\hline \multicolumn{3}{|c|}{ Mining areas } \\
\hline 1 & Low (Adequate erosion control measures) & 1.0 \\
\hline 2 & Moderate (moderate control against soil erosion) & 1.5 \\
\hline 3 & High (poor measures against soil erosion) & 2.0 \\
\hline \multicolumn{3}{|c|}{ Recreational areas } \\
\hline 1 & Low $(\mathrm{A} / \mathrm{P}<1)$ & 1.0 \\
\hline 2 & Moderate $(1<\mathrm{A} / \mathrm{P}<2.5)$ & 1.5 \\
\hline 3 & $\operatorname{High}(\mathrm{A} / \mathrm{P}>2.5)$ & 2.0 \\
\hline
\end{tabular}

\section{Policy enforcement}

Finally, policies related to land protection were classified according to the degree to which they are enforced in each land use class. The information on the existing policies were collected at municipal scale from regional technical offices and then the level of implementation was evaluated. Three classes related to the degree of environmental protection were defined (Table 6).

Table 6. Policy enforcement analysis

\begin{tabular}{c|c|c|c}
\hline Class & Description & Enforcement level & Score \\
\hline 1 & Low & complete $(>75 \%$ of the area under protection) & 1.0 \\
2 & Moderate & partial $(25-75 \%$ of the area under protection) & 1.5 \\
3 & High & incomplete $(<25 \%$ of the area under protection) & 2.0 \\
\hline
\end{tabular}

\section{Computing strategy}

The quantification of different land sensitivity levels at local scale was carried out evaluating the impact individual layers have on the phenomena under investigation (Ferrara et al. 1999). The information should be robust irrespective of the number and 
type of collected information layers. The final output of the illustrated system is a composite index of ESD (ESI) which describes the impact of factors causing desertification risk within a land unit. Fig. 1 summarizes the indicators used to calculate the ESI.

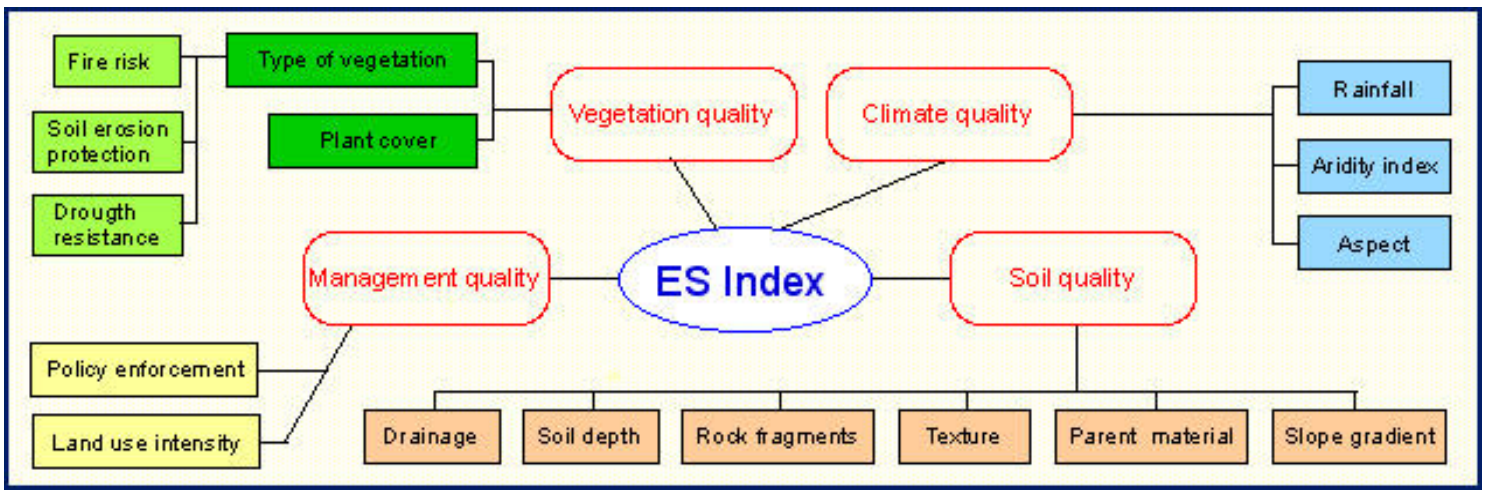

Figure 1. The environmental indicators used to calculate the ESI

A two-step approach was adopted to compute the ESI in each land unit. Thematic quality indicators of climate (CQI), soil (SQI), vegetation (VQI), and land management (MQI) were estimated as the geometric mean of the different scores for each considered variable. ESI was subsequently estimated in each $i$-th spatial unit and $j$-th year as the geometric mean of the four thematic indicators (Basso et al., 2000) as follows:

Equation:

$$
\mathrm{ESI}_{\mathrm{i}, \mathrm{j}}=\left(\mathrm{SQI}_{\mathrm{i}, \mathrm{j}} \times \mathrm{CQI}_{\mathrm{i}, \mathrm{j}} \times \mathrm{VQI}_{\mathrm{i}, \mathrm{j}} \times \mathrm{MQI}_{\mathrm{i}, \mathrm{j}}\right)^{1 / 4}
$$

The ESI score ranges from 1 (the lowest land sensitivity to degradation) to 2 (the highest sensitivity to degradation) and the percentage of 'critical' factors was also calculated based on the ESI score (i.e., 0\% means no critical factors observed in that area, $100 \%$ means that all evaluated layers are critical factors of the ESD in the investigated area). Eight classes of land sensitivity were identified according to the obtained ESI scores. Classes reflect the most used classification thresholds (see Salvati and Zitti, 2008 and references therein) and are reported in Table 7. Intermediate and final ESI maps were produced after the various layers were rasterized, registered and referenced to an elementary $250 \mathrm{~m}$ cell size. The minimum spatial unit was selected according to Basso et al. (2000) as adequate to local scale analysis. Sensitivity scores provide a reliable estimation of different levels of sensitivity occurring in a specific area. Following Kosmas et al. (1999), an example of ESI class grouping that can be considered generally applicable to the Mediterranean region, was reported in Table 7. 
Table 7. Description of the ESI classes identified in this study

\begin{tabular}{|c|c|c|c|c|c|}
\hline \multicolumn{2}{|c|}{$\begin{array}{c}\text { Sensitivity } \\
\text { level }\end{array}$} & Class name & Sensitivity score & $\%$ critical factors & Short description \\
\hline 0 & Very low & $\begin{array}{l}\text { Not affected } \\
(\mathrm{N})\end{array}$ & ESI $<1.170$ & $\geq 0<15.1$ & $\begin{array}{l}\text { Areas in which critical } \\
\text { factors are very low or } \\
\text { not present, with a good } \\
\text { balance between } \\
\text { environmental and } \\
\text { socio-economical factors }\end{array}$ \\
\hline 1 & Low & Potential (P) & $1.170 \leq \mathrm{ESI} \geq 1.225$ & $\geq 15.1 \leq 20.0$ & $\begin{array}{l}\text { Areas threatened by } \\
\text { desertification under } \\
\text { significant climate } \\
\text { change, if a particular } \\
\text { combination of land use } \\
\text { is implemented or where } \\
\text { offsite impacts will } \\
\text { produce severe } \\
\text { problems. This would } \\
\text { also include abandoned } \\
\text { land which is not } \\
\text { properly managed. }\end{array}$ \\
\hline 2 & Medium & $\begin{array}{l}\text { Fragile (F1) } \\
\text { Fragile (F2) } \\
\text { Fragile (F3) }\end{array}$ & $\begin{array}{c}1.225 \leq \mathrm{ESI} \geq 1.265 \\
>1.265 \leq 1.325 \\
>1.325 \leq 1.375\end{array}$ & $\begin{array}{l}>20.0 \leq 23.6 \\
>23.6 \leq 28.9 \\
>28.9 \leq 33.4\end{array}$ & $\begin{array}{l}\text { Areas in which any } \\
\text { change in the delicate } \\
\text { balance between natural } \\
\text { and human activity is } \\
\text { likely to bring about } \\
\text { desertification. }\end{array}$ \\
\hline 3 & High & $\begin{array}{l}\text { Critical (C1) } \\
\text { Critical (C2) } \\
\text { Critical (C3) }\end{array}$ & $\begin{array}{c}>1.375 \leq 1.415 \\
>1.415 \leq 1.530 \\
>1.530\end{array}$ & $\begin{array}{c}>33.4 \leq 36.9 \\
>36.9 \leq 47.2 \\
>47.2\end{array}$ & $\begin{array}{c}\text { Areas already highly } \\
\text { degraded through past } \\
\text { misuse, presenting a } \\
\text { threat to the } \\
\text { environment of the } \\
\text { surrounding areas or } \\
\text { with evident } \\
\text { desertification } \\
\text { processes. }\end{array}$ \\
\hline
\end{tabular}

\section{Study site application}

We applied the DSS-ESI procedure to a vulnerable area in southern Italy (Agri basin) as a study site exercise. The Agri basin is located in Basilicata and is one of the most disadvantaged areas in the Mediterranean Europe. The Agri basin covers $1730 \mathrm{~km}^{2}$ (17\% of Basilicata), with a small part in the neighbouring Campania region (Basso et al., 2000). Using physical-environmental and socio-economic criteria, the Agri basin can be divided into the Upper, Middle and Lower Agri. The Upper region of the valley, above the Pertusillo reservoir, has an average elevation higher than $600 \mathrm{~m}$, an area of just under $600 \mathrm{~km}^{2}$, and is dominated by a valley-floor plain. This region has a population density of almost 50 inhabitants $/ \mathrm{km}^{2}$. The Middle Valley stretches from the Pertusillo reservoir to the confluence of the Sauro and Agri rivers, in the municipality of Stigliano, and occupies $47 \%$ of the catchment. This is an area of badlands, the so called 'calanchi', where the population averages 30 inhabitants $/ \mathrm{km}^{2}$. The Lower Agri Valley, stretching from the Sauro junction to the sea, occupies about $25 \%$ of the basin and has the highest population density with almost 70 inhabitants $/ \mathrm{km}^{2}$. The region includes the 
fertile coastal zone of Metaponto. From a climatic point of view, the basin presents very different regimes. Along the Ionian coast and in the lowest hilly areas up to between 500 and $600 \mathrm{~m}$ a.s.1., the climate is typically Mediterranean with summer droughts and mild winter. In the upper part of the valley the climate becomes more temperate with hot summer and average temperatures of $21^{\circ} \mathrm{C}$. Above $1600 \mathrm{~m}$, the climate is very cold with a long period of snow and annual rainfall up to $2000 \mathrm{~mm}$.

\section{Statistical analysis}

The ESI has been used to evaluate the different levels of sensitivity at local scale in the pilot area. In the present exercise, all collected variables for the pilot area refer to the years 2000 or 2001. For each DSS-ESI layer, an average value was assigned to each municipality through layer computation using the 'zonal statistics' tool provided by ArcGIS software (ESRI, inc., USA). A cluster analysis was carried out to profile the municipalities within the pilot area according to the average value estimated for each individual layer. Cluster analysis was run using the complete linkage algorithm and Euclidean distance agglomeration approach (Salvati and Zitti, 2008).

\section{Results and discussion}

The following paragraph illustrated selected outputs of the DSS-ESI application to the pilot area Agri basin, Basilicata). The proposed analysis underlines the flexibility of the system to describe the factors determining the level of environmental sensitivity at local scale. Fig. 2 illustrates the spatial distribution of the ESI across the pilot area. According to the characteristics of the region, the highest sensitivity to desertification was recorded in flat areas close to the Ionian sea. 


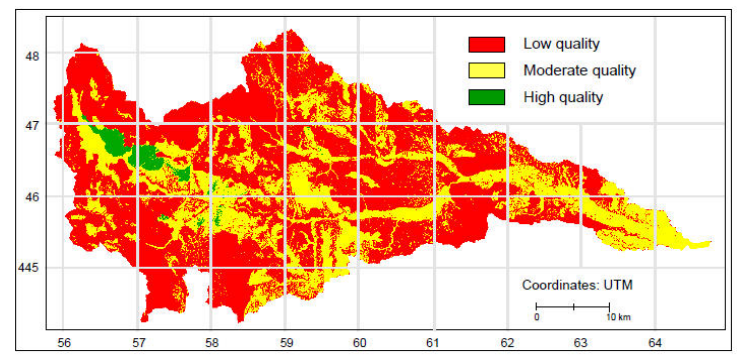

Soil quality

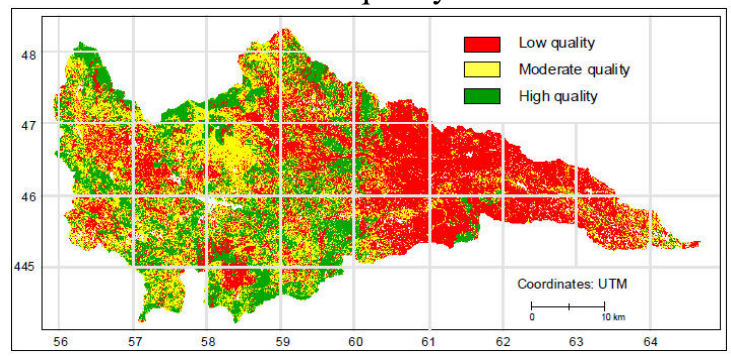

Vegetation quality

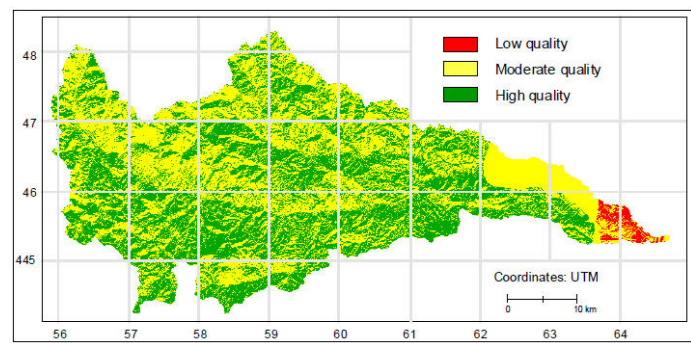

Climate quality

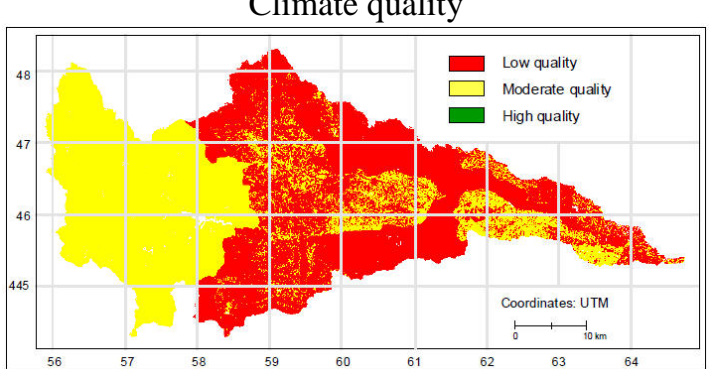

Land management quality

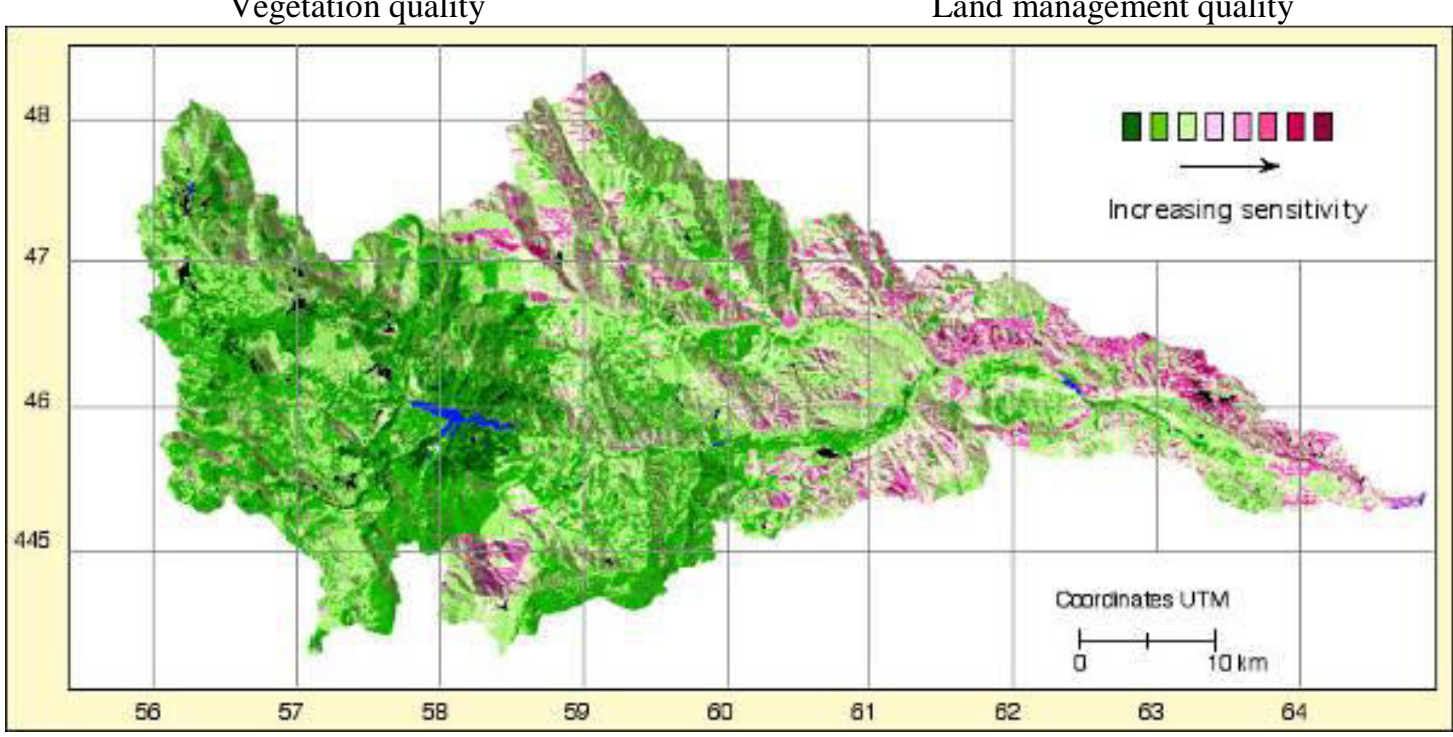

ESI

Figure 2. Thematic indicators and the final ESI map of the pilot area

Since the proposed system is capable to identify factors that contribute to the ESD at land unit scale, it is possible to compare areas with similar levels of sensitivity caused by different 'critical' variables. Fig. 3 showed an example of two land units (located in an upland areas of the Agri basin) with the same ESI score (1.46) and characterized by a different combinations of 'critical' factors. Sensitivity in one land unit was mainly due to poor land management coupled with moderately low climate quality. In the other land unit land sensitivity was mainly due to poor soil properties and climate aridity. 


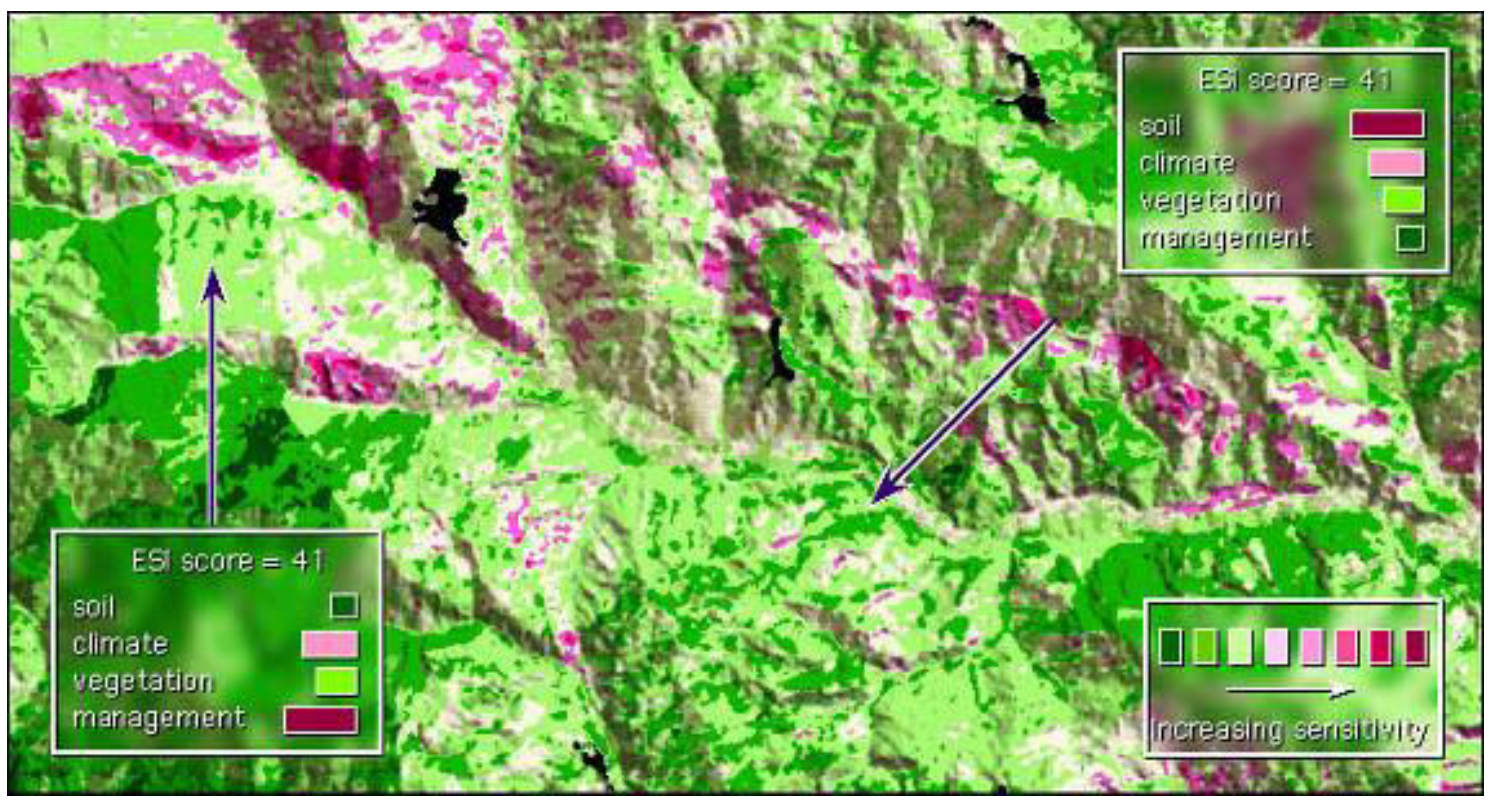

Figure 3. An example of high-resolution ESD cartography through the ESI-DSS in the pilot area

As a result of the DSS, Fig. 4 illustrates the tree clustering profile of the 35 municipality included in the pilot area according to the average value of all layers composing the ESI (Tables 2-6). The analysis identified five municipality groups corresponding to defined degree of sensitivity (from class 1 to class 5) according to the final ESI level.

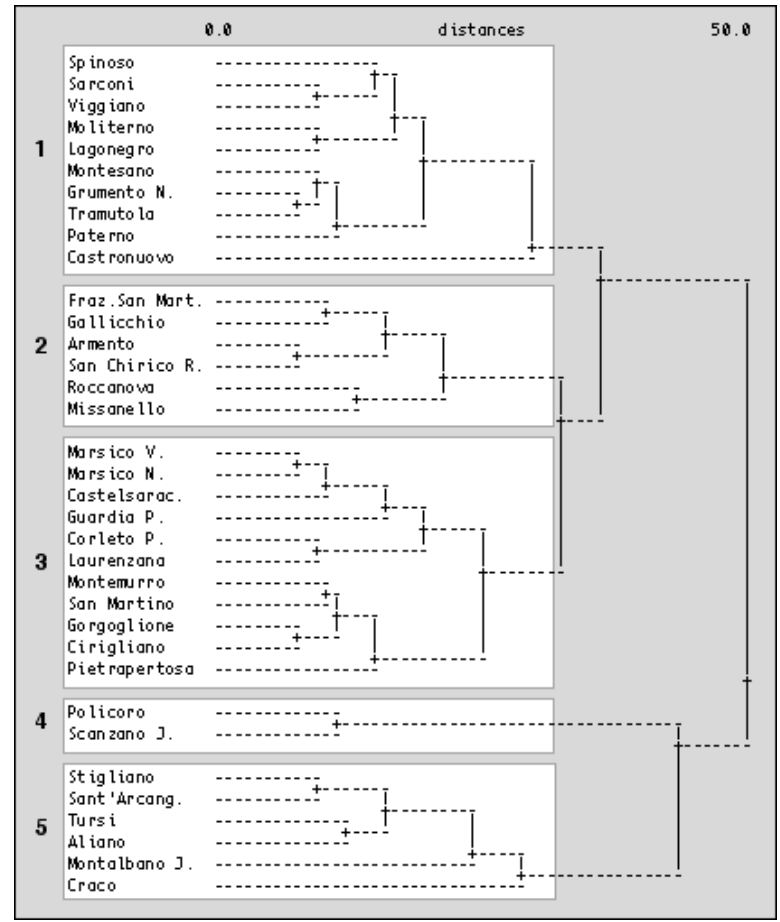

Figure 4. Tree clustering of pilot area municipalities according to the ESI-DSS 
Fig. 5 shows the percentage of the four different quality scores (climate, soil, vegetation, land management) by municipal class. Clusters 1, 2 and 3 showed similar climate quality (the three groups are located in Upper Val d'Agri). Cluster 1 showed poor land management factors and soil properties. Cluster 2 had good vegetation quality and critical land management. Clusters 4 and 5 differed significantly in land management, climate, and vegetation conditions.

These examples emphasise the flexibility of the ESI-DSS: the system allows for the permanent monitoring of both natural and agricultural ecosystems and identifies the possibly beneficial environmental measures that could be introduced to mitigate the sensitivity of a given area. The use of cross analysis techniques, applied to pre-existing information with other ad hoc data, can also be used to investigate specific degradation phenomena. Furthermore, this approach not only allows for the identification of the different ESD levels but, at the same time, helps investigating the factors that cause such conditions.

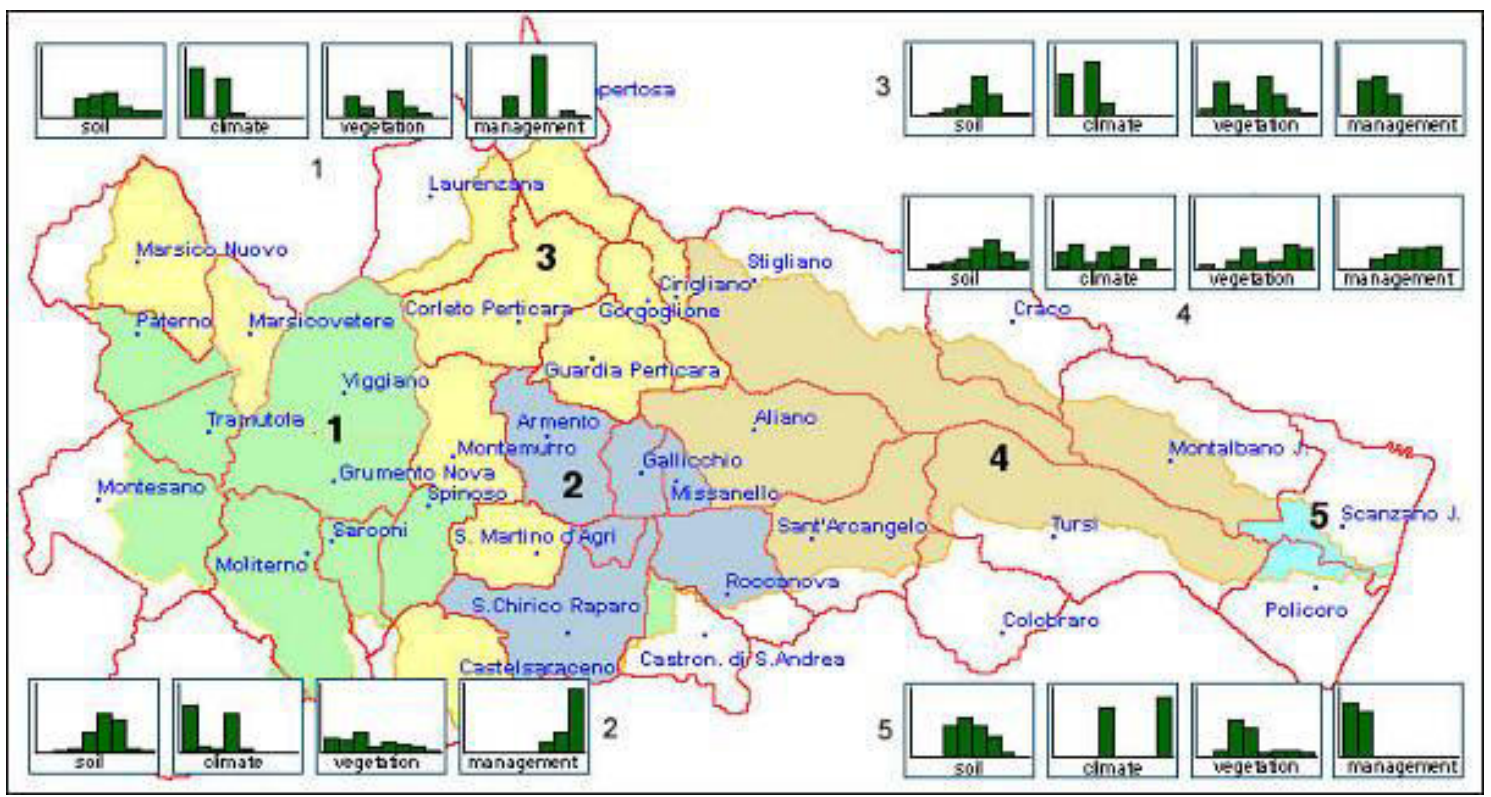

Figure 5. The percentage of the four different quality scores (climate, soil, vegetation, land management) by municipality cluster (profiles are expressed as percent ESI (X-axis ranges from $10 \%$ to $80 \%$; $Y$-axis ranges from $0 \%$ to $75 \%$ )

While analysis can be performed on elementary land units as was shown earlier, it is also possible to calculate sensitivity scores for specific land uses. In the following exercise, the ESI level was evaluated for each crop (or pasture) at farm level (Fig. 6). This tool allows e.g. comparison among farms to examine the impact of different agroenvironmental measures on the ESD. 


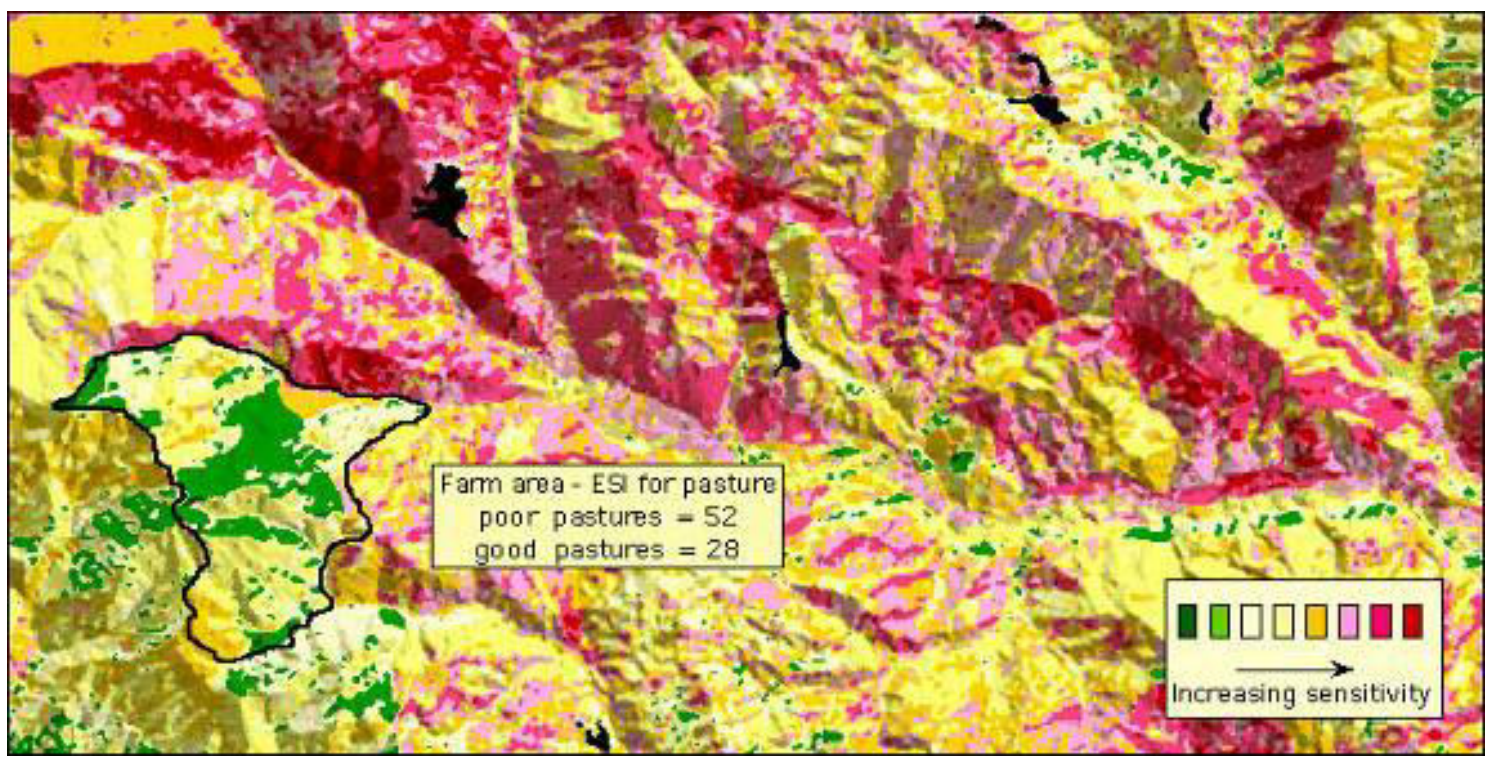

Figure 6. Farm-scale ESI analysis in the pilot area

The ESI-DSS also provides a simple tool for simulating the impact of changing environmental conditions (e.g. climate, land use, soil deterioration) on the ESD. The system was provided with a graphical interface allowing to vary interactively the value of each considered variable and to evaluate the consequent variation in the ESI (Fig. 7).

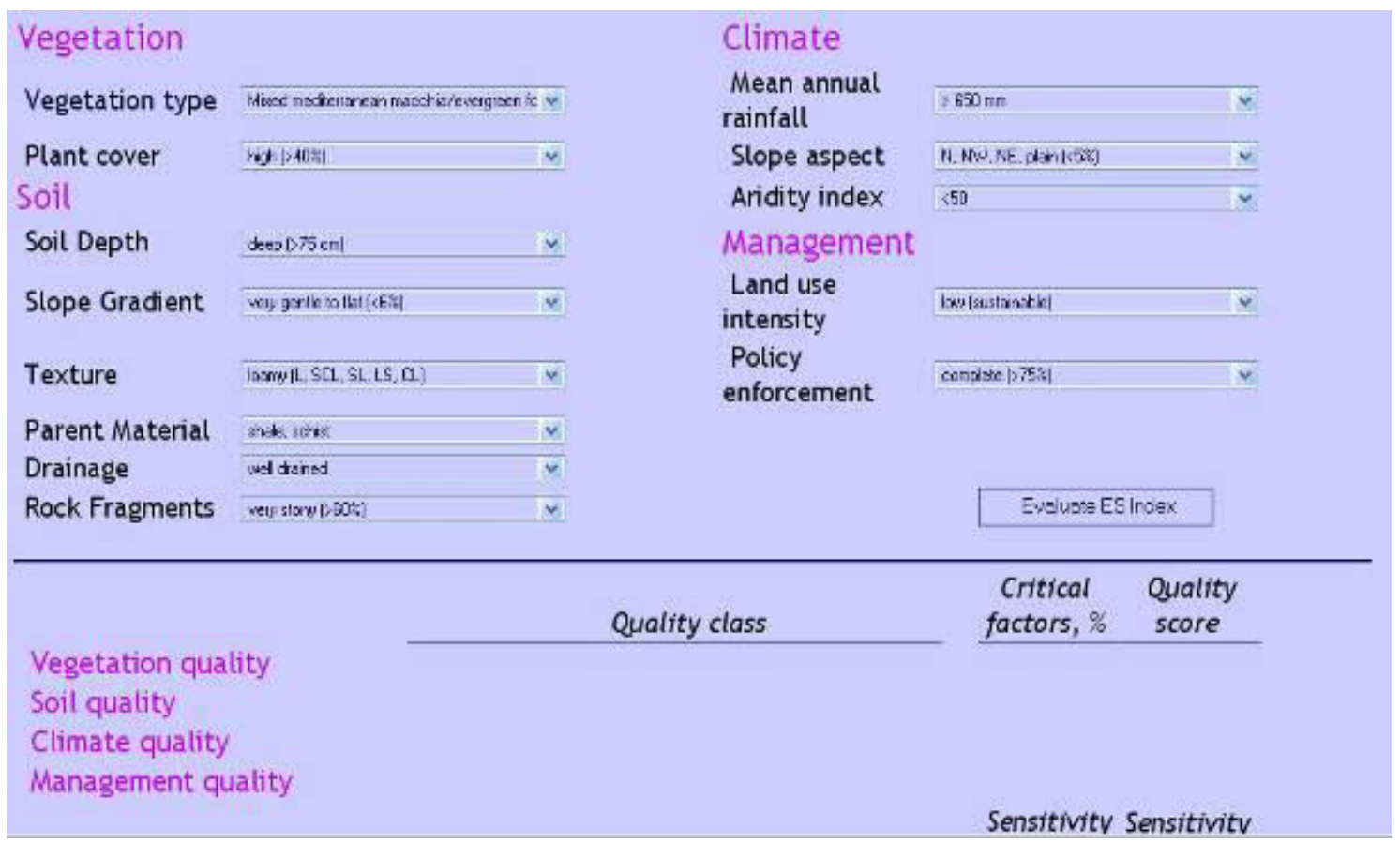

Figure 7. The ESI-DSS simulation tool graphical interface

Fig. 8 illustrates a DSS-ESI application which describe a possible warming scenario coupled with important land use transformation and poor level of environmental 
protection impacting on initially not affected land. The ESI calculation before changes is reported in the upper panel. Climate aridity with land use conversion from natural cover (Mediterranean maquis) towards bare ground due to the long-term impact of fires is illustrated in the lower panel, causing an overall increase in the ESI (passing from 1.0 to 1.5$)$.

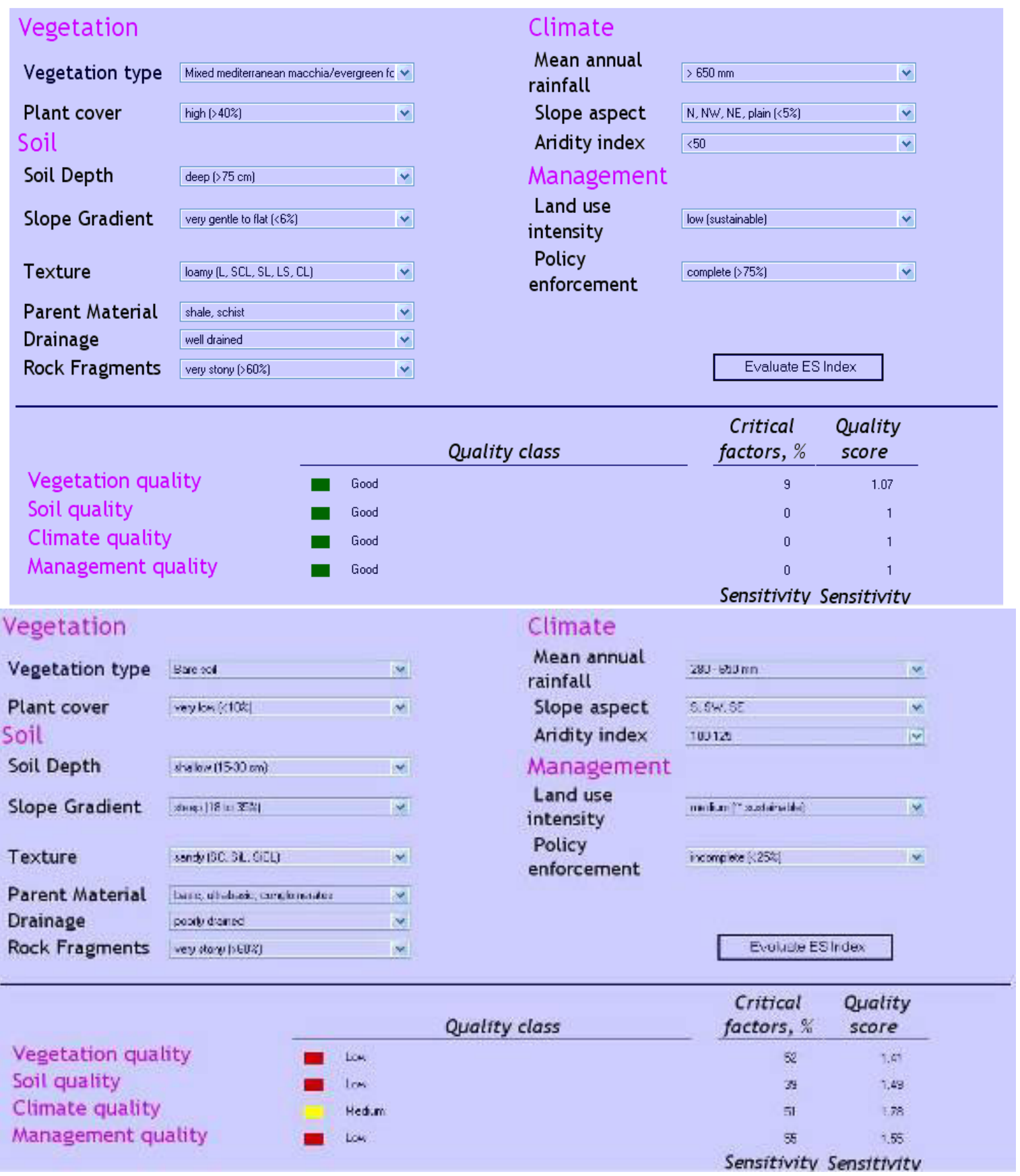

Figure 8. Simulation of short-term climate and land use changes and their impact on the ESI 


\section{Conclusions}

The illustrated DSS represents a simulation tool supporting SLM in sensitive areas to desertification and introduced an original approach specifically informing environmental regional planning policies. The system refers to the well-known, field validated ESA framework and was specifically designed for local-scale desertification monitoring in the Mediterranean basin. It was also capable to consider additional, sitespecific variables depending on the local environmental context (Basso et al., 2000).

It is known that data processing, sampling, and homogenisation may cause a reduction in data accuracy since high-resolution information can be integrated only at the lowest available spatial scale. The same problem applies to the classification procedures used to interpret the different information layers. In fact, classifications simplify the data by summarising multiple attributes values within a restricted number of classes (Salvati and Zitti, 2008). Data interpretation requires homogeneous classifications to organized data into reference systems, or when comparing different ecosystem types (Salvati et al., 2008). These crucial steps in environmental analysis and management were faced by the proposed ESI-DSS in a simple and readable way. As an example, changes in the vegetation quality index due to policy enforcement can be estimated by simulating different land management options, as shown in the study site application. The use of simulation techniques, applied to existing information and supported by ad hoc collected data, can be used also to investigate specific degradation processes (Grainger, 2009), including soil erosion, salinisation, sealing, etc.

Climate variations, soil deterioration, and land use changes should be continuously monitored to inform SLM strategies. The system illustrated here could represent a feasible contribution to desertification monitoring since it is reasonably simple to operate, flexible in the use of relevant, low-cost variables, and widely applicable across the Mediterranean basin.

Acknowledgements. This research was partly supported by DESERTLINKS (Combating Desertification in Mediterranean Europe: Linking Science with Stakeholders) project (EVK2-2001-00045) project (ENV.2009.2.1.3.2).

\section{REFERENCES}

[1] Basso, F., Bove, E., Dumontet, S., Ferrara, A., Pisante, M., Quaranta, G., Taberner, M. (2000): Evaluating Environmental Sensitivity at the basin scale through the use of Geographic Information Systems and Remote Sensed data: an example covering the Agri basin (southern Italy). - Catena 40: 19-35.

[2] Briassoulis, H. (2005): Policy integration for complex environmental problems. Aldershot: Ashgate.

[3] Conacher, A.J., Sala, M. (eds.) (1998): Land degradation in Mediterranean environments of the world. - Wiley, Chichester.

[4] Costantini, E.A.C., Urbano, F., Aramini, G., Barbetti, R., Bellino, F., Bocci, M., Bonati, G., Fais, A., L'Abate, G., Loj, G., Magini, S., Napoli, R., Nino, P., Paolanti, M., Perciabosco, M., Tascone, F. (2009): Rationale and methods for compiling an atlas of desertification in Italy. - Land Degradation and Development, forthcoming.

[5] D’Angelo, M., Enne, G., Madrau, S., Percich, L., Previtali, F., Pulina, G., Zucca, C. (2000): Mitigating land degradation in Mediterranean agro-silvo-pastoral systems: a GISbased approach. - Catena, 40: 37-49. 
[6] Feoli, E., Giacomich, P., Mignozzi, K., Oztürk, M., Scimone, M. (2003): Monitoring desertification risk with an index integrating climatic and remotely-sensed data: an example from the coastal area of Turkey. - Management of Environmental Quality 14: 10-21.

[7] Ferrara, A., Bellotti, A., Faretta, S., Mancino, G., Taberner, M. (1999): Identification and assessment of environmentally sensitive areas by Remote Sensing. - MEDALUS III 2.6.2. OU Final Report. King's College, London. Volume 2: 397-429.

[8] Grainger, A. (2009): The role of science in implementing international environmental agreements: the case of desertification. - Land Degradation and Development, forthcoming.

[9] Kosmas, C., Ferrara, A., Briasouli, H., Imeson, A. (1999): Methodology for mapping Environmentally Sensitive Areas (ESAs) to Desertification. - In: Kosmas, C., Kirkby, M., Geeson, N. (ed.) The Medalus project Mediterranean desertification and land use. Manual on key indicators of desertification and mapping environmentally sensitive areas to desertification, European Union, 18882, pp. 31-47, ISBN 92-828-6349-2.

[10] Kosmas, C., Moustakas, N., Danalatos, N.G., Yassoglu, N. (1994): The effect of rock fragments on wheat biomass production under highly variable moisture conditions in Mediterranean environments. - Catena 23: 191-198.

[11] Kosmas, C., Tsara, M., Moustakas, N., Karavitis, C. (2003): Identification of indicators for desertification. - Annals of Arid Zones 42: 393-416.

[12] Rubio, J.L., Bochet, E. (1998): Desertification indicators as diagnosis criteria for desertification risk assessment in Europe. - Journal of Arid Environment 39: 113-120.

[13] Salvati, L., Zitti, M., Ceccarelli, T. (2008): Integrating economic and environmental indicators in the assessment of desertification risk: a case study. - Applied Ecology and Environmental Research 6: 129-138.

[14] Salvati, L., Zitti, M. (2008): Assessing the impact of ecological and economic factors on land degradation vulnerability through multiway analysis. - Ecological Indicators 9: 357363.

[15] Simeonakis, E., Calvo-Cases, A., Arnau-Rosalen, E. (2007): Land use change and land degradation in southeastern Mediterranean Spain. - Environmental Management 40: 8094. 